\title{
DNA detection of Clostridium difficile infection based on real-time resistance measurement
}

\author{
C. Liu, D.N. Jiang, G.M. Xiang, F.K. Luo, L.L. Liu, J.C. Yu and X.Y. Pu \\ Department of Clinical Laboratory, Xinqiao Hospital, \\ Third Military Medical University, Chongqing, China \\ Corresponding author: X.Y. Pu \\ E-mail: puxiaoyun@yahoo.cn
}

Genet. Mol. Res. 12 (3): 3296-3304 (2013)

Received January 27, 2013

Accepted March 16, 2013

Published September 3, 2013

DOI http://dx.doi.org/10.4238/2013.September.3.6

\begin{abstract}
We used a newly developed electrochemical method, real-time resistance measurement, based on loop-mediated isothermal amplification (LAMP), with real-time resistance monitoring and derivative analysis. DNA extracted from specimens was amplified through LAMP reaction. The 2 products of LAMP, DNA and pyrophosphate, both are negative ions; they combine with positive dye (crystal violet) and positive ions $\left(\mathrm{Mg}^{2+}\right)$, which leads to an increase in the resistivity of the reaction liquid. The changes of resistivity were measured in real-time with a specially designed resistance electrode, to detect Clostridium difficile DNA. We found that electrochemical detection of $C$. difficile could be completed in 0.5-1 h, with a detection limit of $10^{2} \mathrm{CFU} / \mathrm{mL}$, with high accuracy (95.0\%), sensitivity (91.1\%), and specificity (97.3\%) compared to PCR methods. $C$. difficile is commonly associated with antibioticinduced diarrhea. Due to the difficulty in performing anaerobic culture and cytotoxicity neutralization assays, a simple, rapid, sensitive, and accurate method is preferred. We conclude that realtime resistance measurement is a rapid, sensitive, and stable method
\end{abstract}


for the diagnosis of $C$. difficile infection that could be applied to gene chips and pocket instruments.

Key words: DNA detection; Real-time resistance measurement; Loopmediated isothermal amplification; Clostridium difficile

\section{INTRODUCTION}

Recently, polymerase chain reaction (PCR) has become the common method of DNA detection. On the basis of PCR, scientists have developed a series of technologies, such as quantitative real-time PCR (Demidenko and Penin, 2012), multiplex PCR (Becker et al., 2012), chip PCR (Wu et al., 2012), microfluidic PCR (Nagatani et al., 2012), and isothermal PCR (Paris et al., 2011). Loop-mediated isothermal amplification (LAMP) was invented by Notomi et al. (2000), which is characterized as rapid and of high specificity and sensitivity. It uses Bst DNA polymerase at a constant temperature $\left(65^{\circ} \mathrm{C}\right)$ and completes DNA amplification in 20-60 min. In recent years, there has been progress in LAMP in the detection of viruses (Wang et al., 2012), bacteria (Han et al., 2011) and parasites (Abdul-Ghani et al., 2012), food safety (Sowmya et al., 2012), and animal embryo sex identification (Nogami et al., 2008). LAMP is relatively simple and can amplify DNA with high specificity (Mori et al., 2004). With the development of gene chips, more attention has been paid to PCR or LAMP on microfluidic gene chips (Tjong et al., 2011).

There are several determination methods using LAMP. Electrophoresis with the fluorescent dye method is a common technique (Le Roux et al., 2009). Rapid electrophoresis and microchip electrophoresis technology have promoted the level of electrophoresis (Iseki et al., 2007). However, the application of electrophoresis has been restricted because of slow response and strong toxicity of dyes (Paris et al., 2007). The turbidimetric method is another common technique (Tomita et al., 2008). However, it requires opticalelectrical devices to transform and output the results, which are expensive and bulky. It is therefore not suitable with gene chips and pocket instruments (Le Roux et al., 2009).

Clostridium difficile is an anaerobic bacterium. It releases toxins that can cause C. difficile-associated disease (CDAD), such as antibiotic-associated diarrhea and vaginal infections (Chen and Shih, 2011). Rapid and sensitive laboratory diagnostic testing is highly desirable for appropriate treatment of CDAD (Wilkins and Lyerly, 2003). The cytotoxicity assay and toxigenic culture has been considered as the "gold standard" for the diagnosis of CDAD (Cohen et al., 2010). However, they are time-consuming, costineffective, and highly standardized. Other commercial detection methods used are immunoassays, but they are not sensitive enough (Planche et al., 2008; Eastwood et al., 2009). Therefore, a simple, rapid, accurate method for $C$. difficile detection is required.

In the present study, we developed a new electrochemical method for real-time resistance measurement (Jiang et al., 2012), based on LAMP, for the identification of $C$. difficile. This assay consists of DNA extraction from stool specimens, followed by LAMP reaction to detect the $C$. difficile tcdA gene. The 2 LAMP products, DNA and pyrophosphate, 2 kinds of negative ions, were combined with a positively charged dye (crystal violet) and the positive ions $\left(\mathrm{Mg}^{2+}\right)$, leading to an increase in the resistance of the reaction medium. The resistance was real-time monitored by a specially designed resistance elec- 
trode to detect the products of DNA amplification on gene chips and pocket instruments, which need a simple and real-time method of measuring. The scheme of the experiment is shown in Figure 1.

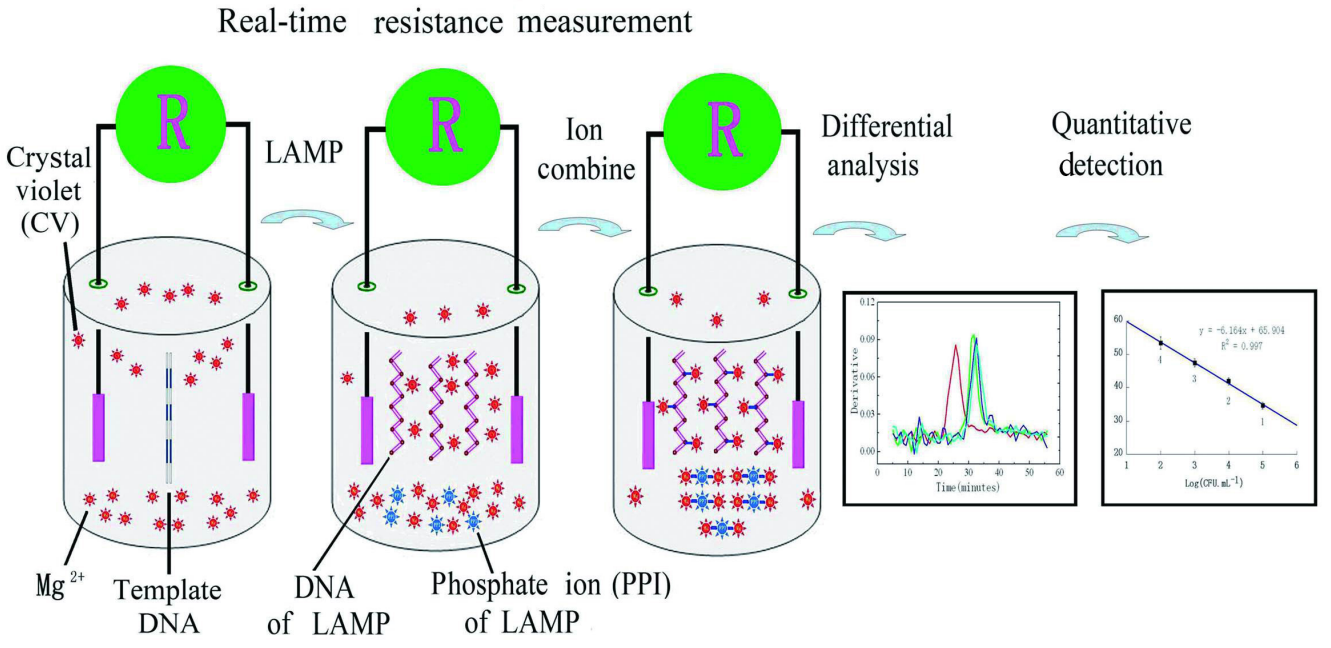

Figure 1. Scheme of the real-time resistance measurement.

\section{MATERIAL AND METHODS}

\section{Reagents}

The LAMP reagents were purchased from Eiken Chemical (Japan). The DNA extraction reagents were provided by Tiangeng (China). Crystal violet was obtained from SigmaAldrich (USA), dissolved in distilled water at a concentration of $100 \mathrm{mg} / \mathrm{L}$, which was diluted to appropriate concentrations before use.

\section{Bacterial strains and growth conditions}

C. difficile (ATCC 43255) and 8 kinds of other bacteria, namely Campylobacter jejuni (ATCC 33291), Salmonella typhimurium (ATCC 14028), Escherichia coli (ATCC 25922), Vibrio parahaemolyticus (ATCC 17802), Shigella dysenteriae (ATCC 13313), Staphylococcus aureus (ATCC 25923), Yersinia enterocolitica (ATCC 23715), and Klebsiella pneumoniae (ATCC 10031), were obtained from the American Type Culture Collection (ATCC, USA), grown on corresponding medium (Pangtong, China), and preserved in normal saline at $-20^{\circ} \mathrm{C}$ until further use.

\section{Collection of CDAD specimens}

The stool samples of patients with CDAD were collected on time and submitted to the 
laboratory for $C$. difficile testing. A total of 120 stool samples were collected from May 2011 to May 2012 from the inpatients of Xinqiao Hospital. The samples were stored at $-80^{\circ} \mathrm{C}$ for later testing.

\section{Primer design and synthesis}

The nucleotide sequences expressed specifically in $C$. difficile were retrieved from the National Center for Biotechnology Information (NCBI) as target genes. The primers were designed using PrimerExplorer 4.0 (Eiken, Japan) online. The primers were synthesized by Sangong (Shanghai, China).

\section{DNA detection}

The DNA was extracted by a bacterial DNA extraction kit (Tiangeng). The amplification was performed in a specific PCR tube containing $2 \mu \mathrm{L}$ DNA extract, $12.5 \mu \mathrm{L}$ reaction reagent, $1 \mu \mathrm{L}$ bst DNA polymerase, $4 \mu \mathrm{L}$ primer mixture $(10 \mu \mathrm{M}$ F3 and B3, $40 \mu \mathrm{M}$ FIP and BIP; Table 1), $1 \mu \mathrm{L} 100 \mathrm{mg} / \mathrm{L}$ crystal violet, and $4.5 \mu \mathrm{L}$ water. The mixture was incubated isothermally at $65^{\circ} \mathrm{C}$ for $60 \mathrm{~min}$ in a Thermo bath ALB64 (Finepcr, Korea). A special electrode was designed for real-time resistance monitoring. The surface of electrode was electroplated with gold to increase its electrochemical stability. The measurements were performed on a VICTOR $86^{\circ} \mathrm{C}$ digital multimeter (Victor, China) with an $\mathrm{Ag} / \mathrm{AgCl}$ electrode as reference, and a resistance electrode as working electrode. The reaction was real-time monitored by the DMM software (Victor). The results were analyzed by the OriginPro 7.5 software (OriginLab, USA).

\begin{tabular}{clll}
\multicolumn{3}{c}{ Table 1. Primers of real-time resistance measurement and PCR. } \\
\hline Target gene & GenBank & Method & Primer $\left(5^{\prime} \rightarrow 3^{\prime}\right)$ \\
\hline tcdA gene & FN545816 & Real-time resistance measurement & F3: AGTTTGTTACAGAACAAGAGTT \\
& & B3: ATCATTCCCAACGGTCTA \\
& & FIP: CCGCCAAAATTTTAGGGCTAATATTTATAGTCAGGA \\
& & GTTGTAAATCG \\
& & BIP: AGATGTTGATATGCTTCCAGGTATTCCAATAGAGCTAG \\
& & GTCTAGG \\
& & F: AGTTGTTACAGAACAAGAGTT \\
& & B: ATTTTATCATTCCCAACGGTCTA \\
\hline
\end{tabular}

\section{Specificity analysis}

C. difficile and 8 bacteria that are diarrhea-associated (C. jejuni, S. typhimurium, E. coli, V. parahaemolyticus, S. dysenteriae, S. aureus, Y. enterocolitica, $K$. pneumoniae) were cultured, counted, diluted to the same concentration $\left[10^{5}\right.$ colony forming units $\left.(\mathrm{CFU}) / \mathrm{mL}\right]$, and submitted to DNA extraction and real-time resistance measurements in the same way.

\section{Sensitivity and regression analysis}

C. difficile was grown at $37^{\circ} \mathrm{C}$ for $48 \mathrm{~h}$. The counts were performed by plating $100 \mu \mathrm{L}$ dilutions in sterile phosphate-buffered saline and incubating for $24 \mathrm{~h}$ at $37^{\circ} \mathrm{C}$. CFU were then 
calculated. The suspension of $C$. difficile was diluted into serial concentrations (from $1 \times 10^{5}$ to $1 \times 10^{\circ} \mathrm{CFU} / \mathrm{mL}$ ), DNA extraction and real-time resistance measurements were performed as previously described. The derivative peak times of real-time resistance measurement were monitored by the OriginPro 7.5 software. The semi-logarithmic linear regression was analyzed by Excel 2003 (Microsoft, USA).

\section{Comparative analysis with PCR}

The samples were divided into 2 parts. One part was identified by real-time resistance, and the other part was amplified by PCR. In the PCR assay, the $25-\mu \mathrm{L}$ multiplex-PCR mixture contained $2.0 \mu \mathrm{M}$ primer F and B (Table 1), $12.5 \mu \mathrm{L}$ 2X Fast qPCR MasterMix (Eurogentec Deutschland GmBH, Germany), and $2.5 \mu \mathrm{L}$ template DNA. Thermal cycling conditions comprised a uracil-N-glycosylase step at $50^{\circ} \mathrm{C}$ for $2 \mathrm{~min}$, hot start DNA polymerase activation at $95^{\circ} \mathrm{C}$ for $5 \mathrm{~min}, 40$ cycles of denaturation at $95^{\circ} \mathrm{C}$ for $3 \mathrm{~s}$, annealing at $64^{\circ} \mathrm{C}$ for $30 \mathrm{~s}$, and extension at $72^{\circ} \mathrm{C}$ for $10 \mathrm{~s}$. The products were analyzed by electrophoresis on $2 \%$ agarose gels (Biowest, Spain) at $100 \mathrm{~V}$ for $50 \mathrm{~min}$, and visualized in a Kodak Gel Logic 212 PRO Imaging System (Eastman Kodak, USA). The results were compared with regard to difference (chisquared test), accuracy $[\mathrm{PCR}(+)$ real-time resistance $(+)$ and $\mathrm{PCR}(-)$ real-time resistance $(-)$ out of all samples], sensitivity [real-time resistance $(+)$ out of PCR $(+)$ ] and specificity [realtime resistance (-) out of PCR(-)].

\section{RESULTS}

\section{Primer design}

The tcdA gene (GenBank: FN545816) of $C$. difficile was chosen to design the primers for real-time resistance measurement of $C$. difficile by exploring the GenBank database of NCBI. The primers of real-time resistance measurement and PCR are shown in Table 1. The specificity of primers had been positively tested by BLAST of NCBI (http://www.ncbi. nlm. nih.gov/blast).

\section{Specificity analysis}

The results of real-time resistance measurement (Figure 2A) and derivative analysis (Figure 2B) showed that $C$. difficile (ATCC43255) was positive and other bacteria were negative. The test suggested a high specificity of LAMP assay for detection of $C$. difficile.

\section{Sensitivity analysis}

The results of real-time curves (Figure 3A) and derivative analysis (Figure 3B) showed that the real-time resistance measurement could be completed in $1 \mathrm{~h}$ with the lowest bacteria level of $10^{2} \mathrm{CFU} / \mathrm{mL}$. It displayed a good performance in the regression analysis (Figure $3 \mathrm{C}$ ). There was a good relationship between C. difficile concentration (logarithm) and the derivative peak time over a range of $1 \times 10^{2}$ to $1 \times 10^{5} \mathrm{CFU} / \mathrm{mL}(\mathrm{y}=60-0.52 \mathrm{x}, \mathrm{R}=0.995)$. Furthermore, the concentration of $C$. difficile in fecal samples could be quantified. 

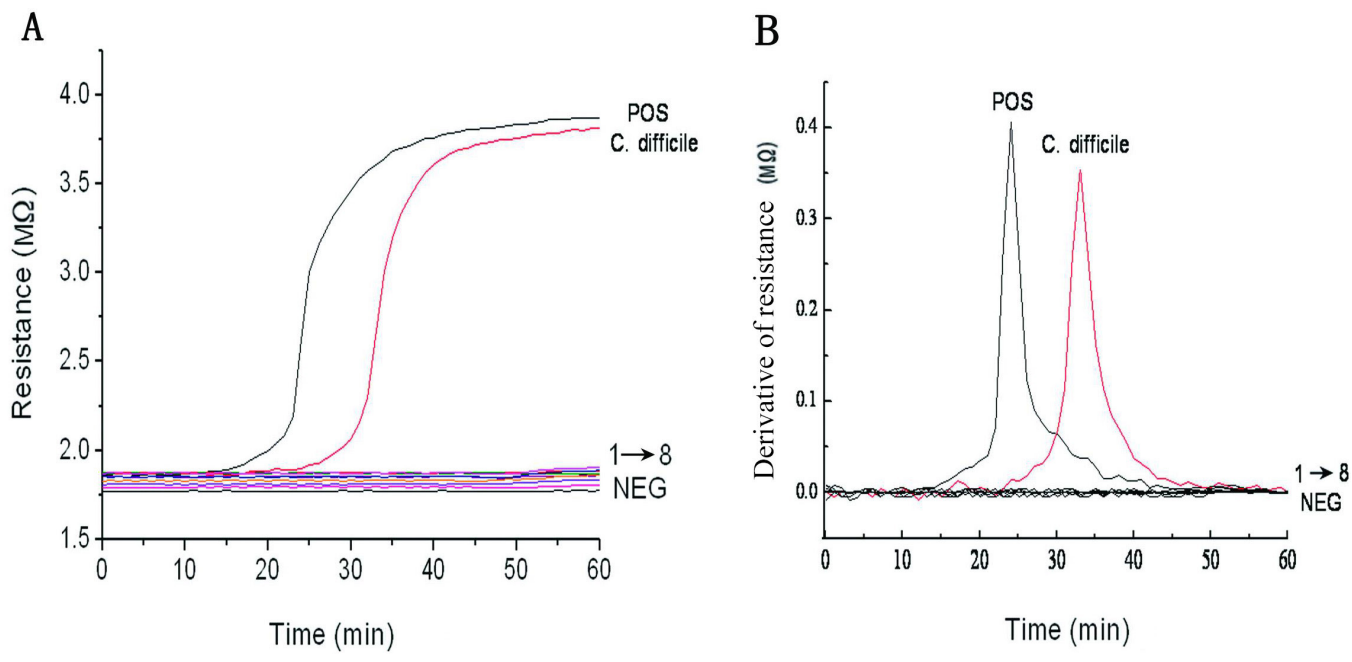

Figure 2. Real-time resistance curves (A) and derivative analysis $(\mathbf{B})$ of the specificity analysis. POS = positive control; NEG = negative control; Clostridium difficile; $1 \rightarrow 8$ : Campylobacter jejuni, Salmonella typhimurium, Escherichia coli, Vibrio parahaemolyticus, Shigella dysenteriae, Staphylococcus aureus, Yersinia enterocolitica, and Klebsiella pneumoniae.
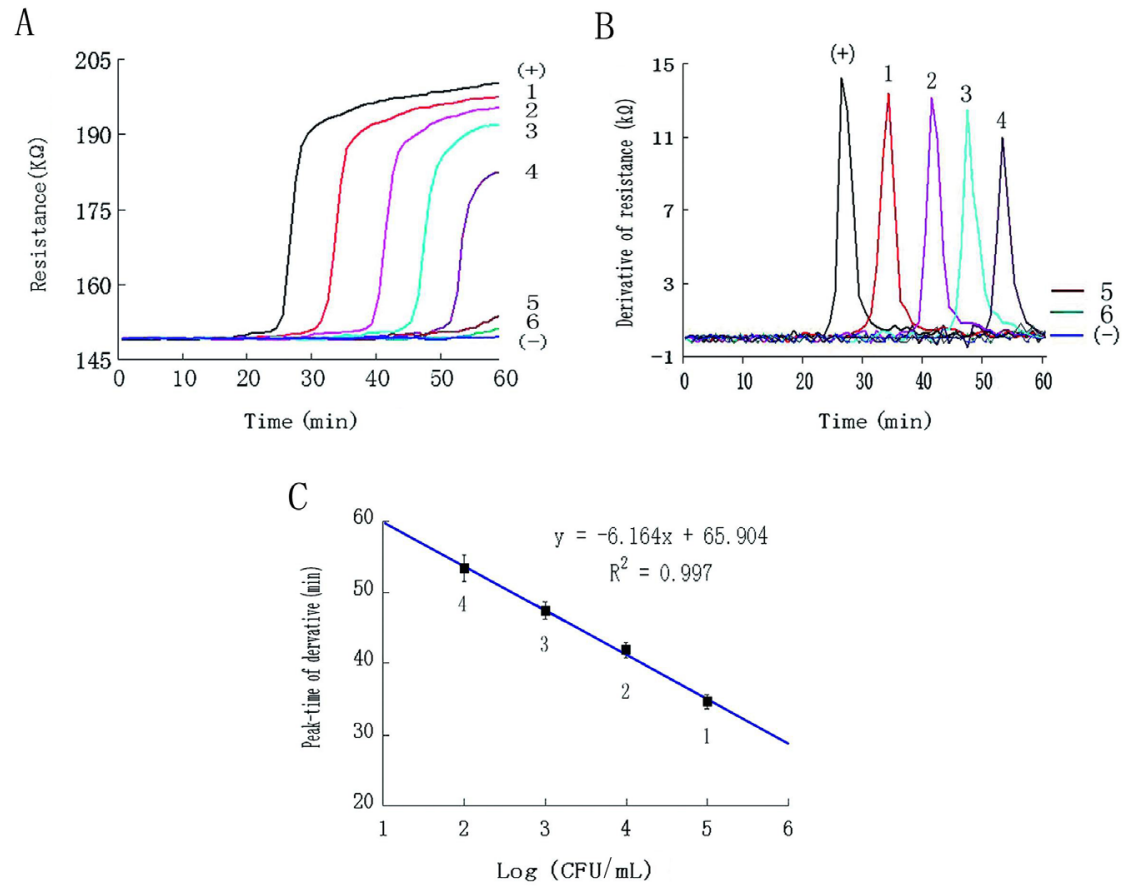

Figure 3. Real-time resistance curves (A), derivative analysis $(\mathbf{B})$, and regression analysis $(\mathbf{C})$ of the real-time resistance measurement. $1 \rightarrow$ 5: Clostridium difficile; $1: 10^{5} \mathrm{CFU} / \mathrm{mL} ; 2: 10^{4} \mathrm{CFU} / \mathrm{mL} ; 3: 10^{3} \mathrm{CFU} / \mathrm{mL} ; 4: 10^{2} \mathrm{CFU} /$ $\mathrm{mL} ; 5: 10 \mathrm{CFU} / \mathrm{mL}$. 


\section{Comparison with PCR}

The results of real-time resistance measurement compared with PCR (Table 2) showed that there was no statistical difference between the two methods (chi-squared test, $\mathrm{P}>0.05$ ). The real-time resistance measurement displayed a high accuracy (95.8\%), sensitivity (91.1\%), and specificity (97.3\%) compared to PCR.

\begin{tabular}{|c|c|c|}
\hline & \multicolumn{2}{|c|}{ PCR } \\
\hline & $(+)$ & $(-)$ \\
\hline \multicolumn{3}{|c|}{ Real-time resistance measurement } \\
\hline$(+)$ & 41 & 2 \\
\hline$(-)$ & 4 & 73 \\
\hline $\mathrm{P}^{\mathrm{a}}$ & 0.167 & \\
\hline$\chi^{2}$ & 0.683 & \\
\hline Âccuracy & $95.0 \%$ & {$[(41+73) / 120]$} \\
\hline Sensitivity & $91.1 \%$ & $(41 / 45)$ \\
\hline Specificity & $97.3 \%$ & $(73 / 75)$ \\
\hline
\end{tabular}

${ }^{\mathrm{a}}$ There was no statistical difference between the two methods $(\mathrm{P}>0.05)$.

\section{DISCUSSION}

PCR has become the common method of DNA detection. On the basis of PCR, scientists have developed a series of technologies, such as chip PCR, microfluidic PCR, and LAMP. With the development of the gene chip, more attention has been paid to PCR or LAMP on microfluidic gene chips. Rapid electrophoresis and microchip electrophoresis technology have promoted the level of electrophoresis. However, slow response and the strong toxicity of dyes have restricted their application. The turbidimetric method is another common determination technique. However, it requires optical-electrical devices to transform and output the results, which are expensive and bulky. It is therefore not suitable for construction on gene chips and pocket instruments.

C. difficile, a spore-forming Gram-positive anaerobic bacillus, is a major cause of healthcare- and antibiotic-associated diarrhea. The most common symptoms of infection include diarrhea, abdominal cramping, and peripheral leukocytosis (Cohen et al., 2010). C. difficile produces toxin $\mathrm{A}$ and $\mathrm{B}$, which cause mucosal damage and fluid secretion leading to diarrhea. A third toxin, binary toxin, has been suggested that binary toxin may improve the adhesion of bacteria to target cells (Schwan et al., 2009). C. difficile infection can range in severity from asymptomatic to severe and life-threatening. Epidemiological trends in the last decade have shown marked increases in incidence, severity, persistence, and mortality of CDAD (Tenover et al., 2010). Unfortunately, the lack of a rapid, accurate, and inexpensive diagnostic test for CDAD remains an important barrier to clinical and epidemiological containment of the disease.

In this study, we developed an electrochemical detection, real-time resistance method for the amplification and detection of $C$. difficile. First, the $C$. difficile tcdA gene (GenBank: FN545816) was chosen as the target gene, and the primers were designed using PrimerExplorer 4.0 (Eiken) online. DNA extracted from specimens was then amplified by the LAMP reaction. The two amplification products, DNA and pyrophosphate, are 2 kinds of negative ions. 
They were combined with the positively charged dye (crystal violet) and positive ions $\left(\mathrm{Mg}^{2+}\right)$, leading to an increase in the resistivity of the reaction medium. The changes of resistivity were real-time monitored by special designed resistance electrode. The results indicated that it had a good specificity. Furthermore, it was demonstrated that this electrochemical detection can be completed in 1-2 $\mathrm{h}$ with a detection limit of $10^{2} \mathrm{CFU} / \mathrm{mL}$. The real-time resistance measurement had a high accuracy $(95.0 \%)$, sensitivity $(91.1 \%)$ and specificity $(97.3 \%)$ compared to PCR. Thus, it is a rapid, sensitive and stable method that can be used with gene chips and pocket instruments, which need a simple and real-time method of measuring.

\section{ACKNOWLEDGMENTS}

Research supported by the Major Research Project of Chongqing Science and Technology Commission (CSTC, \#2011AB5035).

\section{REFERENCES}

Abdul-Ghani R, Al-Mekhlafi AM and Karanis P (2012). Loop-mediated isothermal amplification (LAMP) for malarial parasites of humans: would it come to clinical reality as a point-of-care test? Acta Trop. 122: 233-240.

Becker CA, Ramos F, Sellal E, Moine S, et al. (2012). Development of a multiplex real-time PCR for contagious agalactia diagnosis in small ruminants. J. Microbiol. Methods 90: 73-79.

Chen N and Shih SL (2011). Images in clinical medicine. Pseudomembranous colitis. N. Engl. J. Med. 364: e8.

Cohen SH, Gerding DN, Johnson S, Kelly CP, et al. (2010). Clinical practice guidelines for Clostridium difficile infection in adults: 2010 update by the society for healthcare epidemiology of America (SHEA) and the infectious diseases society of America (IDSA). Infect. Control Hosp. Epidemiol. 31: 431-455.

Demidenko NV and Penin AA (2012). Comparative analysis of gene expression level by quantitative real-time PCR has limited application in objects with different morphology. PLoS One 7: e38161.

Eastwood K, Else P, Charlett A and Wilcox M (2009). Comparison of nine commercially available Clostridium difficile toxin detection assays, a real-time PCR assay for $C$. difficile tcdB, and a glutamate dehydrogenase detection assay to cytotoxin testing and cytotoxigenic culture methods. J. Clin. Microbiol. 47: 3211-3217.

Han HJ, Jung SJ, Oh MJ and Kim DH (2011). Rapid and sensitive detection of Streptococcus iniae by loop-mediated isothermal amplification (LAMP). J. Fish Dis. 34: 395-398.

Iseki H, Alhassan A, Ohta N, Thekisoe OM, et al. (2007). Development of a multiplex loop-mediated isothermal amplification (mLAMP) method for the simultaneous detection of bovine Babesia parasites. J. Microbiol. Methods 71: 281-287.

Jiang DN, Xiang GM, Wu JH, Liu C, et al. (2012). A Real-time resistance measurement for DNA amplification and detection. Int. J. Electrochem. Sc. 7: 5273-5285.

Le Roux CA, Kubo T, Grobbelaar AA, van Vuren PJ, et al. (2009). Development and evaluation of a real-time reverse transcription-loop-mediated isothermal amplification assay for rapid detection of Rift Valley fever virus in clinical specimens. J. Clin. Microbiol. 47: 645-651.

Mori Y, Kitao M, Tomita N and Notomi T (2004). Real-time turbidimetry of LAMP reaction for quantifying template DNA. J. Biochem. Biophys. Methods 59: 145-157.

Nagatani N, Yamanaka K, Ushijima H, Koketsu R, et al. (2012). Detection of influenza virus using a lateral flow immunoassay for amplified DNA by a microfluidic RT-PCR chip. Analyst 137: 3422-3426.

Nogami H, Tsutsumi H, Komuro T and Mukoyama R (2008). Rapid and simple sex determination method from dental pulp by loop-mediated isothermal amplification. Forensic Sci. Int. Genet. 2: 349-353.

Notomi T, Okayama H, Masubuchi H, Yonekawa T, et al. (2000). Loop-mediated isothermal amplification of DNA. Nucleic Acids Res. 28: E63.

Paris DH, Imwong M, Faiz AM, Hasan M, et al. (2007). Loop-mediated isothermal PCR (LAMP) for the diagnosis of falciparum malaria. Am. J. Trop. Med. Hyg. 77: 972-976.

Paris DH, Blacksell SD, Nawtaisong P, Jenjaroen K, et al. (2011). Diagnostic accuracy of a loop-mediated isothermal PCR assay for detection of Orientia tsutsugamushi during acute Scrub Typhus infection. PLoS Negl. Trop. Dis. 5: e1307.

Planche T, Aghaizu A, Holliman R, Riley P, et al. (2008). Diagnosis of Clostridium difficile infection by toxin detection 
kits: a systematic review. Lancet Infect. Dis. 8: 777-784.

Schwan C, Stecher B, Tzivelekidis T, van HM, et al. (2009). Clostridium difficile toxin CDT induces formation of microtubule-based protrusions and increases adherence of bacteria. PLoS Pathog. 5: e1000626.

Sowmya N, Thakur MS and Manonmani HK (2012). Rapid and simple DNA extraction method for the detection of enterotoxigenic Staphylococcus aureus directly from food samples: comparison of PCR and LAMP methods. J. Appl. Microbiol. 113: 106-113.

Tenover FC, Novak-Weekley S, Woods CW, Peterson LR, et al. (2010). Impact of strain type on detection of toxigenic Clostridium difficile: comparison of molecular diagnostic and enzyme immunoassay approaches. J. Clin. Microbiol. 48: 3719-3724.

Tjong V, Yu H, Hucknall A, Rangarajan S, et al. (2011). Amplified on-chip fluorescence detection of DNA hybridization by surface-initiated enzymatic polymerization. Anal Chem. 83: 5153-5159.

Tomita N, Mori Y, Kanda H and Notomi T (2008). Loop-mediated isothermal amplification (LAMP) of gene sequences and simple visual detection of products. Nat. Protoc. 3: 877-882.

Wang X, Zhu JP, Zhang Q, Xu ZG, et al. (2012). Detection of enterovirus 71 using reverse transcription loop-mediated isothermal amplification (RT-LAMP). J. Virol. Methods 179: 330-334.

Wilkins TD and Lyerly DM (2003). Clostridium difficile testing: after 20 years, still challenging. J. Clin. Microbiol. 41: 531-534.

Wu J, Kodzius R, Xiao K, Qin J, et al. (2012). Fast detection of genetic information by an optimized PCR in an interchangeable chip. Biomed. Microdevices. 14: 179-186. 